\title{
KECENDERUNGAN MEMAKAI CADAR DI KOTA BANDA ACEH DAN ACEH BESAR: KAJIAN LIVING HADIS
}

\author{
Maizuddin \\ Universitas Islam Negeri Ar-Raniry Banda Aceh \\ maizuddin72@gmail.com \\ Suarni \\ Universitas Islam Negeri Ar-Raniry Banda Aceh \\ suarni23@yahoo.com
}

\begin{abstract}
The article aims at describing the tendency of wearing a veil in Banda Aceh City and Aceh Besar District, which has recently increased significantly. It employs living hadith as a concept with a qualitative method that seeks to explore hadiths that living in Muslim societies, how they are applied and made into traditions in daily life. The article argues that the use of the veil was more based on selfprotection than on theological motivation. However, they still held that wearing veil is a sunna. This circumcision is then understood in a totalistic ideal typology, which leads to the implementation of Sunna in a higher level of application. Besides, women who wear a veil feel more filled with religious nuance, which manifests in the attitude of iffah (self-care), islāh (improvement of knowledge and behavior) and izzah (feeling noble). Also, the religiosity of a veiled female affects in two aspects: socio-morality and psychological aspect.

Keywords: veil, motivation, sunna.
\end{abstract}

Abstrak: Artikel ini mendeskripsikan kecenderungan memakai cadar di Kota Banda Aceh dan Kabupaten Aceh Besar yang akhir-akhir ini meningkat secara signifikan. Kaca mata yang digunakan adalah living hadis dengan metode kualiatif yang berusaha mengekplorasi hadis yang hidup dalam masyarakat Muslim, bagaimana diaplikasikan dan dijadikan tradisi dalam keseharian. Hasil penelitian menunjukkan bahwa pemakaian cadar lebih banyak didasari oleh motivasi perlindungan diri. Meski demikian, bagi mereka cadar tetap dipahami sebagai sebuah sunah. Sunah ini kemudian dipahami dalam tipologi ideal totalistik sehingga mengarahkan pada pelaksanaan sunah 
semaksimal mungkin. Di sisi lain, wanita yang memakai cadar merasakan nuansa relegiusitas dibanding sebelum menggunakan, yang tersimpul dalam sikap iffah (keterpeliharan diri) iṣlah (perbaikan pengetahuan dan perilaku) dan izzah (merasa mulia dan dihargai). Perasaan 'izaah ini merupakan kelanjutan dari pearasaan 'iffah dan islah. Selain itu, religiusitas wanita bercadar juga berdampak pada dua aspek, yaitu aspek sosio-moral dan aspek psikologis.

Kata Kunci: cadar, motivasi, sunah.

\section{Pendahuluan}

Agama sebagai sebuah sistem kepercayaan dan ritual telah memainkan perannya dalam membentuk pikiran dan perilaku manusia. Seperti yang dikatakan Clifford Geertz, ${ }^{1}$ wahyu membentuk suatu struktur psikologis dalam benak manusia yang membentuk pandangan hidupnya, yang menjadi sarana individu atau kelompok yang mengarahkan tingkah laku mereka. Wahyu bukan saja menghasilkan budaya imaterial, tetapi juga dalam bentuk seni suara, ukiran, bangunan. Itu sebabnya Emile Durkheim menyatakan bahwa agama merupakan sumber kebudayaan yang paling tinggi nilainya. ${ }^{2}$

Salah satu perilaku yang dipengaruhi oleh agama adalah cara berpakaian menutup aurat. Di Indonesia, belakangan ini semakin terlihat banyak perempuan yang memakai cadar. Kutipan dari Kompasinia ${ }^{3}$ mensinyalir semakin banyaknya perempuan yang menggunakan cadar seperti di Jakarta, Bandung, Makasar, Poso dan Riau. Meski demikian, perempuan bercadar belum dapat diterima secara luas di tengah masyarakat. Di Indonesia, wajah telah lama dikenal sebagai sumber informasi dan identifikasi diri dalam interaksi dan komunikasi interpersonal. Bahkan dalam beberapa kepentingan administrasi, identifikasi wajah seseorang sangat diperlukan. Cadar tentu saja dapat menjadi penghalang dalam komunikasi dan interaksi interpersonal tersebut. Di samping itu, stigma yang melekat pada perempuan bercadar sebagai penganut Islam fundamentalis dan lekat dengan 'teroris' masih begitu kuat dalam masyarakat.

${ }^{1}$ Clifford Geertz, Kebudayaan Dan Agama (Yogyakarta: Kanisius, 1992), 13.

${ }^{2}$ Thomas F. Odea, Sosiologi Agama: Suatu Pengantar (Jakarta: Rajawali Press, 1993), 3.

3Sholehuddin Abdul Aziz, 'Misteri Di Balik Wanita Bercadar ???', dalam http:// wmw.kompasiana.com/sholehudinaaziz/misteri-di-balik-wanita-

bercadar_54fef0e3a33311854b50f836. Diakses tanggal 20 September 2017. 
Begitu pula di Kota Banda Aceh dan Kabupaten Aceh Besar, belakangan ini terlihat semakin banyak perempuan, baik dari kalangan mahasiswa di beberapa perguruan tinggi maupun perempuan yang sudah bekerja dan berkeluarga yang menggunakan cadar. Seperti penulis alami sendiri, ketika memberikan perkuliahan, terutama mata kuliah bidang-bidang ilmu keislaman, terdapat peningkatan jumlah mahasiswa yang memakai cadar hingga mendekati angka sepuluh orang dalam satu perkuliahan. Beberapa di antaranya adalah mahasiswi yang sebelumnya tidak memakai cadar. Demikian juga informasi yang disampaikan oleh Samsul Bahri, dia mensinyalir adanya peningkatan jumlah mahasiswa yang menggunakan cadar. ${ }^{4}$ Fenomena ini dapat dipahami bahwa kecenderungan menutup aurat pada bagian kepala lebih dari sekedar jilbab semakin meningkat.

Fenomena ini menarik untuk diteliti dengan berbagai pendekatan. Salah satunya adalah pendekatan living hadis yang belakangan ini marak diperbincangkan. Penelitian-penelitian hadis pada umumnya berpijak pada penelitian-pelitian teks yang umumnya cenderung memisahkan kajiannya dengan konteks. Oleh karena itu, kajian teks ini menjadi terasa kering dan jauh dari realitas problem kehidupan masyarakat. Di sisi lain, kajian living hadis seperti yang dipaparkan oleh Alfatih Suryadilaga merupakan studi yang dilakukan untuk menelaah gejalagejala sosial yang terdapat dalam masyarakat berupa sikap dan perilaku yang sumber pengetahuan dan pemahamannya terindikasi mengacu pada hadis-hadis Nabi. ${ }^{5}$ Sehingga, hadis nabi seakan hidup dan mentradisi dalam masyarakat. Menurutnya ada tiga model living sunah dalam masyarakat, yaitu: tradisi lisan, tradisi tulisan dan tradisi praktik. Model-mdel tersebut merupakan bagian dari respon umat Islam dalam interaksi mereka terhadap hadis-hadis Nabi Muhammad. ${ }^{6}$ Kajian tersebut bertujuan untuk mengekplorasi hadis yang hidup dalam masyarakat Muslim untuk melihat hadis diaplikasikan dan dijadikan sumber inspirasi dalam kehidupan keseharian. Dengan demikian, penelitian living hadis berangkat dari analisa historis dan fenomena sosial atas hadis-hadis Nabi yang hidup dan mentradisi dalam masyarakat.

\footnotetext{
${ }^{4}$ Wawancara dengan Samsul Bahri, dosen Ulum al-Qur'an, tanggal 20 Maret 2018 ${ }^{5} \mathrm{M}$. Alfatih Suryadilaga, "Implementasi Pendekatan Integrasi-Interkoneksi Dalam Kajian Living Hadis," dalam Islamic Studies: Paradigm Integrasi-Interkoneksi Sebuah Antologi (Yogyakarta: Suka Press, 2007), 170.

"Alfatih Suryadilaga, "'Model-Model Living Hadis," dalam Metodologi Penelitian Living Qur'an Dan Hadis, ed. Sahiron Syamsuddin (Yogyakarta: TH Press, 2007), 116.
} 
Berangkat dari latar belakang belakang masalah di atas, penelitian living hadis dalam persoalan kecenderungan pemakaian cadar yang meningkat di kota Banda Aceh dan di Kabupaten Aceh Besar ini penting untuk dilakukan. Penelitian living hadis ini akan didekati dengan pendekatan yang ada dalam ilmu hadis sekaligus dengan pendekatan yang ada dalam kajian sosiologi. Ada tiga aspek penting yang akan dideskripsikan, yaitu 1) proses pemakain cadar yang meliputi motivasi, tantangan, dan kronologis pemakaiannya, 2) pandangan tentang cadar sebagai sunah yang meliputi gambaran tentang tradisi cadar di masa Nabi, dan pengetahuan serta model pemahaman terhadap sunah, dan 3) religiusitas wanita bercadar.

Penelitian ini yang dilakukan terhadap 20 (dua puluh) orang wanita yang menggunakan cadar di Kota Banda Aceh dan Kabupaten Aceh Besar dengan kriteria tersendiri. Pemilihan subjek penelitian atau responden dalam penelitian ini dilakukan dengan cara purposive sampling atau judgement sampling yaitu pemilihan subjek penelitian dengan pertimbangan-pertimbangan tertentu yang disesuaikan dengan tujuan penelitian, yaitu wanita-wanita yang memamakai cadar. Selanjutnya pengambilan sampel dilakukan dengan metode bola salju (snowball) atau sampel berantai (chain sampling). Teknik pengumpulan data dilakukan dengan teknik wawancara, studi dokumen dan Focussed group discussion (FGD). Sedangkan analisis data dimulai dengan pengecekan keabsahan data, reduksi data, tabulasi, pembahasan dan penarikan kesimpulan.

\section{Proses Pemakaian Cadar}

Bagi sebagian orang, memakai cadar tentu merupakan sebuah tindakan sadar yang berproses. Artinya, memakai cadar bukan tindakan yang tiba-tiba dan spontan. Sebagai sebuah tindakan yang berproses, ia terkait dengan motivasi, kendala dan waktu yang dibutuhkan dalam memutuskan diri untuk tampil dengan wajah berbalut cadar.

Hasil penelitian menunjukkan bahwa motivasi perlindungan diri dalam memakai cadar jauh lebih mendominasi motivasi lainnya seperti motivasi teologis, psikologis atau menyenangkan keluarga serta taat aturan. 
Tabel 1

Jumlah Jenis Motivasi Wanita Memakai Cadar

di Kota Banda Aceh dan Aceh Besar

\begin{tabular}{|c|l|c|c|}
\hline No & \multicolumn{1}{|c|}{ Jenis Motivasi } & $\begin{array}{c}\text { Jml } \\
\text { Partisipan }\end{array}$ & Persentase \\
\hline 1. & $\begin{array}{l}\text { Perlindungan diri: menjaga dan } \\
\text { membatasi diri }\end{array}$ & 11 & $55 \%$ \\
\hline 2. & $\begin{array}{l}\text { Teologis: mengikuti sunah, } \\
\text { meneladani istri dan putri Nabi }\end{array}$ & 4 & $20 \%$ \\
\hline 3. & Psikologi: rasa nyaman dan adem & 2 & $10 \%$ \\
\hline 4. & $\begin{array}{l}\text { Menyenangkan keluarga: taat } \\
\text { orang tua dan suami }\end{array}$ & 2 & $10 \%$ \\
\hline 5. & Taat aturan JUMLAH & 20 & $100 \%$ \\
\hline & \multicolumn{1}{|c|}{ JUMH } \\
\hline
\end{tabular}

Dari tabel di atas dapat dimaknai bahwa kebutuhan akan perlindungan diri perempuan sangat tinggi di era modern. Perlindungan diri dimaksudkan di sini bukanlah perlindungan diri dari kekerasan terhadap perempuan. Tetapi, perlindungan diri bahwa dia dipandang lebih berharga, tidak menjadi objek segerombol orang yang berbentuk siulan, sapaan, atau bahkan komentar yang bersifat menggoda dan tak enak untuk didengar yang lebih dikenal dengan catcalling. Catcalling sendiri dapat menimbulkan efek negatif bagi si korban. Dibalik kegembiraan dan canda pelaku, bisa jadi korban mengalami trauma bahkan ketakutan berlebihan untuk bepergian. ${ }^{7}$

Digunakannya cadar sebagai alat kontrol diri berangkat dari pandangan bahwa pakaian cadar sebagai pakaian wanita Muslimah yang terhormat dan berwibawa. Ia tidak dipakai kecuali oleh orangorang yang menjaga kehormatan dan martabatnya dengan baik, tidak memberi peluang timbulnya fitnah dan gaduh dalam masyarakat. Setelah memakai cadar, perasaan nyaman kemudian muncul, terutama merasa aman dari lirikan laki-laki yang menggoda. Wanita bercadar ini menyadari bahwa semakin cantik seorang wanita, laki-laki semakin sulit menundukkan pandangan matanya. Hal ini akan berdampak buruk bagi wanita itu sendiri. Menurut mereka cadar telah

${ }^{7}$ Religius Perdana, "Fenomena Catcall, Perempuan bukan Objek Lelucon", dalam www.kompasiana.com, 19 April 2017. 
menjauhkan mereka dari tatapan laki-laki yang menggoda. Seorang responden menyatakan bahwa sebelum ia bercadar, seorang laki-laki yang tertarik kepadanya sering datang mengunjunginya di rumah dan di kampus. Tetapi setelah ia memakai cadar, ia tidak lagi dikunjungi laki-laki tersebut.

Berkenaan dengan motivasi teologis, motivasi mengikuti teladan dari putri Rasulullah Sayyidah Fatimah dan isteri-isteri Rasulullah merupakan sumber inspirasi bagi para pemakai cadar. ${ }^{8}$ Dapat dikatakan bahwa motivasi ini biasanya muncul dari pendalaman pengetahuan tentang sejarah Islam, baik dari bacaan-bacaan, videovideo maupun dari kajian-kajian keislaman. Motivasi teologis ini didasari oleh keimanan, sementara motivasi kenyamanan dapat dipahami muncul secara spontan dan tidak memerlukan telaah dan kajian terhadap makna cadar dalam Islam. Motivasi ini muncul begitu saja ketika melihat wanita yang tampil dengan pakaian cadar. Motivasi ini semakin tumbuh dan kuat sejalan dengan intentistas seseorang melihat wanita yang menggunakan cadar.

Berdasar pada tiga motivasi bercadar di atas, para wanita memberi makna yang ideal pada cadar sebagai media perlindungan diri. Cadar, bagi mereka, adalah pakaian yang dapat melindungi diri dari sesuatu yang mencemaskan dan merendahkan perempuan, menjaga diri agar tidak larut dengan situasi yang dalam pandangan agama dan masyarakat tidak dapat diterima, dan bahwa cadar adalah pakaian yang dapat menentramkan hati mereka ketika berinteraksi dengan masyarakat luas.

Sementara itu, dua motivasi ekstrinsik yang diungkapkan partisipan, yaitu motivasi menyenangkan keluarga dan motivasi mengikuti aturan yang ditetapkan tidak memaknai cadar secara tersendiri. Tetapi, ini tidak berarti bahwa kemudian cadar tidak memiliki nilai baginya. Makna cadar dapat tumbuh dan berkembang kemudian setelah menggunakannya. Karena itu, beberapa partisipan tetap menggunakan cadar meski tidak lagi di pondok pesantren. Begitu pula perempuan yang awalnya keberatan memakai cadar, tetapi kemudian merasa senang dengan cadar yang digunakannya.

${ }^{8}$ CNA, Wawancara, Banda Aceh, 30 Juni 2018. 
Gambar 1

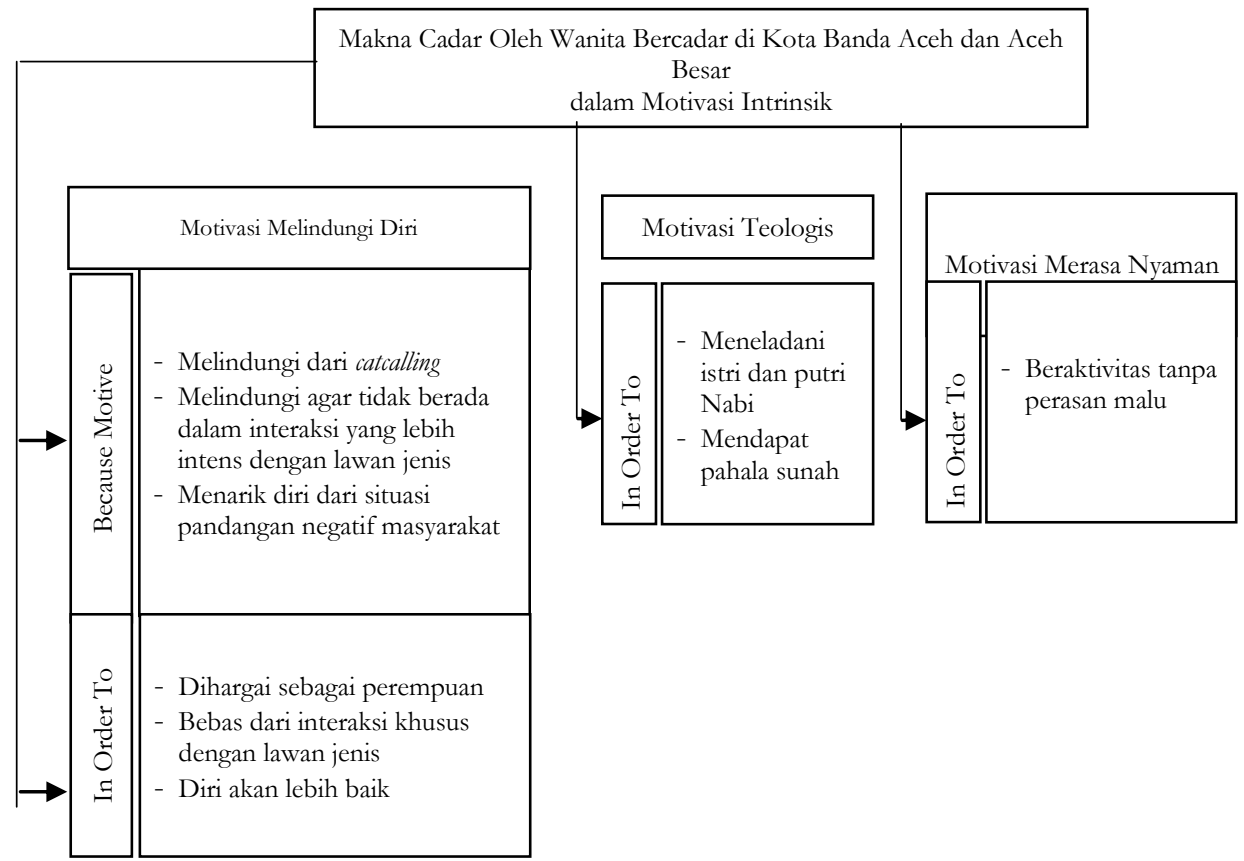

Ada banyak tantangan yang didapat oleh wanita-wanita yang menggunakan cadar, baik tantangan saat hendak mengenakan cadar maupun ketika baru mengenakan cadar. Tantangan yang dihadapi wanita bercadar bersifat internal dan ekternal. Tantangan internal atau dari dalam diri sendiri adalah perasaan kelayakan memakai cadar. Ini juga memberi makna pada cadar bahwa ia merupakan simbol perilaku baik sebagai sorang Muslimah. Sebagian responden menyatakan bahwa mereka telah mengoleksi beberapa lembar cadar tetapi sudah beberapa minggu belum menggunakannya.'

Tantangan kelayakan diri dalam menggunakan cadar ini terutama dirasakan oleh wanita-wanita yang merasa diri jauh dari sikap seorang Muslimah, baik dalam berinteraksi dengan lawan jenis maupun sikap kepribadian. Sebagian patisipan bahkan membutuhkan waktu tiga bulan atau bahkan sampai satu tahun untuk memastikan diri tampil dengan menggunakan cadar. Dalam waktu yang relatif lama tersebut, upaya perbaikan sikap dan perilaku diri terus dibenahi. Sehingga, dalam tipe ini, seseorang berusaha untuk memantaskan diri terlebih

9 TM, Wawancara, Banda Aceh, 28 Juni 2018. 
dahulu untuk menjadi wanita Muslimah yang taat, baru kemudian dia berani untuk menampakkan identitas Muslimahnya dengan memakai cadar.

Sedangkan tantangan dari luar adalah dari keluarga, terutama orang tua. Tantangan dari orang tua ini umumnya di latar belakangi oleh faktor budaya keluarga yang masih asing dengan cadar. Selain itu, mereka juga khawatir atas masa depan anak perempuannya yang diasumsikan akan kesusahan mendapatkan pekerjaan dan jodoh karena menggunakan cadar. Dalam hal ini, upaya untuk meyakinkan orang tua oleh para pemakai cadar merupakan tantangan paling berat dalam mewujudkan diri memakai cadar.

Terkait dengan tantangan ini, terutama dari keluarga, sebagian responden menjalani proses bercadar dengan beberapa tahap, mulai dari memakai masker ketika menjalankan aktivitas di luar, memakai cadar secara terbatas khususnya ketika berada di luar kampung halaman. Bagi sebagian orang, memakai masker dalam menjalankan aktivitas di luar rumah didasarkan oleh alasan medis. Namun bagi para calon pemakai cadar, aktivitas ini merupakan tahapan untuk membiasakan diri menutup menutup bibir, hidung dan pipi. Dengan kebiasaan memakai masker ini, mereka berharap keluarga tidak terkejut ketika melihatnya memakai cadar. Di satu sisi, cadar jelas lebih indah dari sekedar masker. Sedangkan menggunakannya dalam wilayah tertentu, di mana ia tidak dikenal oleh suatu kominitas yang tinggal di wilayah yang sama, adalah karena alasan menghindari stigma negatif.

Tantangan lain dari dalam adalah adanya persepsi bahwa wanita bercadar identik dengan aliran keagamaan yang fundamentalis, ekslusif dan radikal. Semua responden mendeskripsikan adanya pandangan masyarakat terhadap hal tersebut. Namun para responden wanita bercadar tersebut menilai bahwa pandangan masyarakat tersebut tidak seluruhnya benar. Meski demikian, sebagaimana motif bercadar yang telah diuraikan di awal, bahwa perasaan untuk menjaga diri lebih mendominasi aktivisme bercadar ini, maka stigma negatif tersebut dengan sendirinya terkalahkan dengan perasaan nyaman, terjaga dan lebih disegani sebagai seorang perempuan.

Dari keinginan bercadar hingga tampil dalam balutan cadar, masing-masing responden membutuhkan waktu yang berbeda. Masa yang paling lama adalah enam bulan. Hal ini karena, keinginan memakai cadar mendapat respon yang kurang baik dari keluarga. 
Sebagian dari responden mengambil beberapa strategi seperti yang telah dijelaskan di atas, namun sebagian lainnya, meskipun tidak mendapat dukungan dari keluarga, mereka tetap memakai cadar. Pada keaadaan seperti ini, mewujudkan keputusan tampil dalam wajah cadar tidak memakan waktu yang lama.

Setelah memakai cadar, masih terdapat tantangan lain, yaitu penyesuaian diri dengan cadar seperti perasaan sesak nafas, kepanasan dan kesulitan untuk makan. Tantangan ini cukup umum dialami oleh apra responden dan mayoritas wanita bercadar. Namun, seiring dengan waktu yang berjalan tantangan ini memudar karena telah menjadi habitus baru. Tantangan ini hanya persoalan pembiasaan, yakni penyesuaian dari keadaan tidak bercadar dengan keadaan setelah memakai cadar. Tantangan lain yang dirasakan adalah rasa akan kehilangan teman. Tetapi tantangan ini tidak terlalu kuat. Tantangan ini memudar dengan sendirinya dengan didapatnya temanteman lain yang berpakaian dan berpikiran sama. Bahkan sebagian merasa senang berada di tengah-tengah lingkungan yang memberi motivasi satu sama lain.

Konsistensi bercadar merupakan tantangan selanjutnya dalam proses pemakaian cadar oleh wanita. Pada tahap ini tantangan masih didapatkan, yaitu pikiran-pikiran yang ingin membuka kembali cadar. Karena ketika mereka konsisten memakai cadar, maka ketika ada kepentingan-kepentingan mendadak yang membuat wanita harus keluar rumah, maka ada perasaan sukar ketika ingin memakai cadar kembali.

Dengan demikian, proses pemakaian cadar di kalangan wanita di Kota Banda Aceh dan Aceh Besar, dapat dilihat dalam empat proses, yaitu: memperoleh motivasi, meyakinkan keluarga, pertimbangan kelayakan diri untuk tampil bercadar, penyeusaian diri dan konsisten dalam memakai cadar. 
Gambar 2

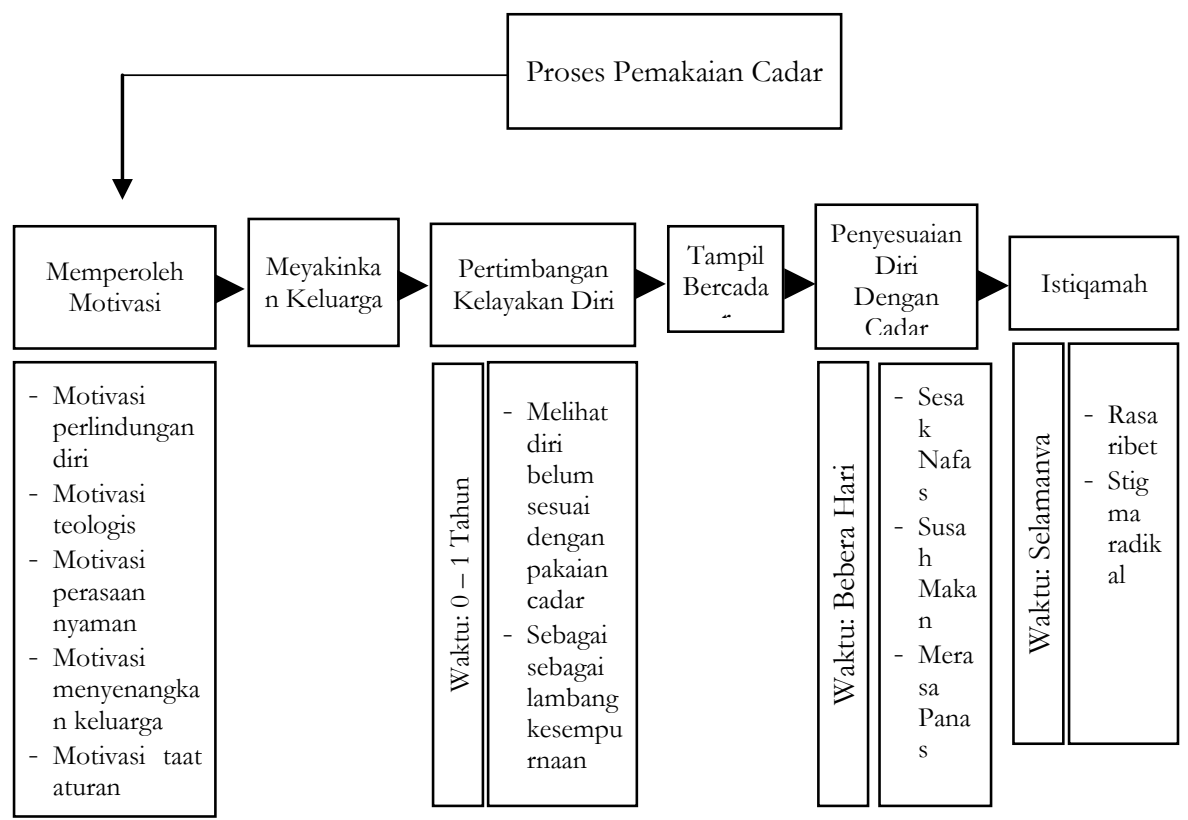

\section{Pengetahuan dan Pemahaman Hadis Wanita Bercadar}

Terlepas dari apa yang memotivasi wanita menggunakan cadar, mereka menyadari bahwa memakai cadar merupakan bagian dari sunah. Memakai cadar merupakan tindakan yang dipraktekkan isteriisteri Nabi dan kaum Muslimah pada masa Islam awal dan bukan merupakan warisan budaya Arab. Sebagian partisipan mengakui masih ada perdebatan di kalangan ulama apakah menggunakan cadar yang dipraktekkan di kalangan isteri Rasul dan kaum wanita pada masa itu adalah sunah atau bukan. Tetapi mereka memilih pendapat yang mengatakan pemakaian cadar sebagai sunah. ${ }^{10}$

Pandangan bahwa cadar sebagai sunah didasari pada pengetahuan mereka dari hadis atau riwayat tentang isteri Nabi. Meskipun kemudian para partisipan pada umumnya tidak lagi dapat menyebutkan secara persis dalil-dalil yang menunjukkan sebagai sebuah sunah, tetapi para partisipan ini pernah mendengar atau membacanya. Dalam lintasan sejarah Islam, terdapat riwayat bahwa sebagian isteri Nabi disebutkan memakai cadar seperti yang telah dijelasakan pada bab sebelumnya. 'A'i'shah dalam beberapa riwayat

${ }^{10} \mathrm{AH}$, Wawancara, Banda Aceh, 27 Juni 2018. 
diungkapkan menggunakan cadar ketika Nabi Muhammad menikahi Safiyah. ${ }^{11}$

Dari 'Abd Allāh b. 'Umar berkata: Seorang laki-laki datang lalu berkata: "Wahai Rasulullah, pakaian apa yang baginda perintahkan untuk kami palai ketika ihram)? Nabi menjawab: "Janganlah kalian mengenakan baju, celana, sorban, mantel (pakaian yang menutupi kepala) kecuali seseorang yang tidak memiliki sandal, hendaklah dia mengenakan sepatu tapi dipotongnya hingga berada dibawah mata kaki dan jangan pula kalian memakai pakaian yang diberi minyak wangi atau wewangian dari daun tumbuhan. Dan wanita yang sedang ihram tidak boleh memakai cadar (penutup wajah) dan sarung tangan". 12

Dari 'A' 'ishah dia berkata: orang-orang yang berkendaraan melewati kami sementara kami sedang berihram bersama Rasulullah, kemudian apabila mereka dekat dengan kami maka salah seorang diantara kami menutupkan jilbabnya dari kepala ke wajahnya, kemudian apabila mereka telah melewati kami maka kami membukanya." 13

Dari 'A' 'ishah dia berkata, "Tatkala Nabi datang ke Madinah, dan beliau sedang menjadi pengantin baru dengan Șafiyah b. Huyay. Datanglah wanita-wanita Ansar menyebarkan kabar tentangnya. Maka aku menyamar dengan memakai cadar lantas pergi. Rasulullah melihat ke mataku dan mengetahuinya. Maka aku berpaling dan mempercepat jalan, tetapi beliau menyusulku seraya mendekapku dan bertanya: "Bagaimana pendapatmu?" Dia berkata, "Aku berkata, "Kirimlah seorang wanita Yahudi pada sekelompok wanita Yahudi.", 14

Terdapat banyak hadis yang dijadikan dasar penggunaan cadar, tetapi sebagiannya sama sekali tidak menyebutkan kata cadar sama sekali. Dari beberapa hadis yang dijadikan petunjuk menggunakan

${ }^{11}$ Muḥammad b. Yazìd al-Qazwinìi b. Mājah, Sunan Ibn Mäjah, vol. 1 (Riyad: Dār alMacárif li al-Nashr wa al-Tawzì), 363.

${ }^{12} \mathrm{Abu}$ 'Abd Allāh Muhammad b. Ismā̄il al-Bukhāri, Șaḥị̣ al-Bukhāri, Vol. 3 (Beirut: Dār Ibn Kathìr li al-Tibā'‘ah wa al-Tawzi'‘, 2002), 15.

${ }^{13} \mathrm{Abu}$ Dāwūd Sulaymān b. al-Ash'ath, Sunan Abī Dāwūd, vol. 2, (Riyad: Bayt alAfkār al-Dawliyah), 167.

${ }^{14}$ Ibn Mäjah, Sunan Ibn Mäjah, vol. I, 636. 
cadar, tidak ada satu pun hadis yang secara langsung memerintahkan penggunaan cadar. Dengan demikian, hadis-hadis yang menginformasikan tentang pemakaian cadar semuanya hadis-hadis fi $\overparen{i}$ (perilaku), yaitu hadis-hadis yang berupa gambaran mengenai keadaan Nabi atau lainnya berkaitan dengan aktivitas bercadar. Tidak ada satu hadis qawli, hadis yang berupa ucapan Nabi yang menyatakan sesuatu tentang cadar, kecuali hadis yang melarang penggunaan ketika ihram. Berkaitan dengan hal ini dapat dinyatakan bahwa tidak terdapat perintah Nabi menutup wajah dengan menggunakan cadar. Bahwa penggunaan cadar oleh para isteri Nabi dan sebagian wanita Muslimah dapat dipahami sebagai takrir Nabi di mana beliau tidak melarang penggunaannya.

Dari tiga hadis di atas, hadis pertama adalah hadis yang paling banyak dikemukakan oleh wanita bercadar sebagai dalil yang menyatakan bahwa memakai cadar adalah sunah. Meskipun tidak dapat menyebut secara sempurna, tetapi mereka dapat menyebut secara substansi bagian akhir dari hadis tersebut. Bagian kalimat dari hadis: Dan wanita yang sedang ibram tidak boleh memakai cadar (penutup wajah) dan sarung tangan, dipahami bahwa memakai cadar merupakan tradisi kaum perempuan pada waktu itu. Sebab bila tidak, maka Rasulullah tidak mungkin melarang mereka menggunakannya ketika dalam ihram. Larangan tersebut bisa diasumsikan bahwa pemakaian cadar yang justru luas dipraktikkan oleh masyarakat Arab. Pemahaman hadis ini diperkuat dengan hadis kedua yang menyatakan bahwa wanita-wanita yang sedang ihram bersama Nabi ketika berpapasan dengan orang-orang (laki-laki), kaum wanita tersebut mengulurkan jilbab mereka hinga menutupi wajah.

Tetapi riwayat-riwayat tentang cadar ini, sebagiannya terkait dengan tanakkur (menyamarkan diri dari orang lain). Artinya, isteri Nabi menutup wajahnya menggunakan cadar agar tidak dikenali. Dalam hadis disebutkan 'A' 'ishah menggunakan cadar ini dengan maksud tanakekur dua kali. Pertama, ketika pada malam hari dia menguntit Rasulullah karena beliau keluar dari rumah ' $\overline{\mathrm{A}}$ 'ishah saat menjelang tengah malam. ${ }^{15}$ Kedua, ketika 'A' 'ishah ingin melihat Șafiyah yang hendak menikah dengan Rasulullah. Aspek tanakkur inilah yang belum tampak dalam pembicaraan para partisipan.

\footnotetext{
${ }^{15}$ Hadis ini diriwayatkan oleh al-Bukhāri dalam matan yang sangat panjang. Lihat alBukhāri, Șahịh al-Bukhāri, vol. 5, 116.
} 
Dalam kaitannya sebagai sebuah sunah, ia dipandang ideal untuk diikuti. ${ }^{16}$ Itulah sebabnya aspek tanakkur yang disebutkan dalam sebagian hadis tidak menjadi perhatian dalam memakai cadar. Praktik isteri dan putri Rasulullah seperti ' $\overline{\mathrm{A}}$ 'ishah dan Fạtimah dengan menggunakan cadar merupakan teladan ideal sebagai tashri' (sesuatu yang dimaksudkan sebagai syariat dan untuk diikuti). Dengan mengikuti teladan ideal ini, seseorang dipandang telah menjalankan agamanya dengan baik dan sempurna.

Pada tipologi pemahaman kewenangan sunah seperti ini, pendalaman alasan rasional ('illab) yang menjadi dasar munculnya sebuah sunah tidak menjadi penting. Atas dasar itu, aspek tanakkur pemakaian cadar dalam hadis tersebut tidak menjadi penting. Begitu pula pembedaan sunah tashriciyah (sunah yang dimaksudkan untuk diikuti dan diteladani) dan ghayr tashriciyah (sunah yang tidak dimaksudkan untuk diikuti dan diteladani) tidak menjadi penting. Hal ini disebabkan semua sunah dipandang ideal dan mengikat kaum Muslim. Karena itu, tindakan yang dikedepankan adalah berusaha sejauh mungkin mengamalkan semua sunah.

Berbeda dengan tipologi ideal 'retrifistik' yang memandang sunah bersifat ideal terbatas pada penjelasan keagamaan. Hal ini didasarkan atas pandangan bahwa Nabi sebagai Rasul juga memiliki sisi-sisi manusiawinya yang terkadang perilaku dan ucapan beliau muncul dalam kapasitas beliau sebagai manusia biasa. Dalam hal penjelasan keagamaan sunah harus dipandang ideal. Tetapi, sunah yang muncul dari pribadi beliau sebagai manusia biasa tidak harus dipandang bersifat ideal. Hal ini didasarkan atas hadis Nabi riwayat Muslim yang menyatakan: Apa yang aku perintabkan berkenaan dengan agamamu, maka laksanakanlah. Apa yang aku perintabkan berdasarkan pendapat pribadiku, maka aku adalah manusia biasa. ${ }^{17}$

Dalam pandangan para ahli usūl yang diformulasikan secara lebih spesifik oleh tokoh-tokoh pembaharu, sunah yang ditampilkan oleh Nabi dan sahabat tidak selalu dimaksudkan sebagai syariat untuk diikuti. Artinya, ada juga sunah yang tidak dimaksudkan sebagai syariat dan tidak untuk diikuti. Substansi pembedaan ini seperti yang diungkapkan Tarmizi M. Jakfar telah diperkenalkan oleh ahli usū

${ }^{16} \mathrm{CNA}$, Wawancara, Banda Aceh, 30 Juni 2018.

17 Abū al-Ḥusayn Muslim b. al-Ḥajjāj al-Naysābūri, Șaḥiḥ Muslim, vol. 4 (Beirut: Dār al-Kutub al-'Tlmiyah, 1991), 1835. 
klasik $^{18}$ dan kemudian dipertegas oleh tokoh-tokoh pembaharu belakangan seperti Yüuf al-Qaradāwi dengan istilah tashriciyah dan ghayr tashriciyah. ${ }^{19}$ Sunah non tashriciyah ini muncul dari sisi kemanusiaan Nabi, adat kebiasaan dan respon sebagai seorang pemimpin atas situasi dan kondisi umat. Implikasinya adalah bahwa sunah non tashriciah ini tidak harus mengikat kaum Muslim untuk diamalkan dan dijalani.

Di sisi lain, hadis-hadis yang disebutkan adalah hadis taqriri (penetapan), tidak ada hadis yang bersifat qawli (ucapan) dari Nabi yang memerintahkan untuk memakai cadar. Dalam studi hadis dikenal tiga jenis hadis Nabi yang berimplikasi hukum, yaitu hadis qawli, hadis fili, dan hadis taqriri. Hadis qawli adalah hadis yang berupa ucapan Nabi secara langsung. Hadis fi't $\bar{i}$ adalah hadis yang berupa perbuatan Nabi yang diceritakan oleh sahabat. Sedangkan hadis taqriri adalah hadis yang berupa perbuatan sahabat yang diketahui Nabi, tetapi Nabi tidak memberi respon dalam bentuk malarang perbuatan tersebut, namun Nabi hanya mendiamkan saja. Masing-masing kategori hadis ini memiliki implikasi tersendiri. Hadis qaw/i dapat ditentukan implikasi hukumnya dalam berbagai kategori hukum secara tersendiri karena dapat dilihat dari bentuk bahasanya. Hadis fit $\overline{l i}$ juga dapat dilihat implikasi hukumnya dari frekuensi perbuatan Nabi dalam berbagai kategori hukum. Sedangkan hadis taqrïi tidak dapat ditentukan hukum dalam kategori hukum yang lain kecuali kategori hukum kebolehan (mubāh).

Dalam hadis dijelaskan bahwa istri-istri Nabi pernah memakainya dan sebagian memakainya karena kepentingan tertentu. Dalam kaitannya dengan hadis taqriri, dia hanya memberikan petunjuk bahwa perbuatan tersebut merupakan suatu kebolehan. Penyimpulan bahwa memakainya adalah sunah terkait dengan pandangan adanya unsur maslahat bagi wanita dalam pemakaian cadar. Itu sebabnya dari segi

\footnotetext{
${ }^{18}$ Tarmizi M. Jakfar menginventarisir beberapa istilah yang menunjukkan sunah tidak untuk diikuti, seperti lays fîh sunnah (bukan untuk diteladani), là bih iqtidä' (tidak untuk diikuti), laysat bi qurbah (tidak untuk mendekatkan diri kepada Allah), là imtisäk bib (tidak untuk jadi pegangan), dan là ḅukm lah așlan (tidak mengandung hukum sama sekali). Lihat Tarmizi M. Jakfar, Otoritas Sunah Non-Tasyrĩiyyah Menurut Yusuf Al-Qaradhawi (Yoyakarta: Ar-Ruz Media, 2011), 125.

${ }^{19}$ Istilah sunah tasrīiyah dan ghayr tashri iyah ini dibahas secara khusus oleh Yüsuf al-

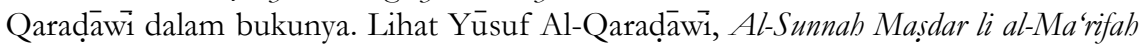
wa al-Had̄ārah (Mesir: Dār al-Shurūq, 2002).
} 
hukum memakai cadar semua partisipan menyatakan sebagai anjuran (sunah), bukan sebagai suatu keharusan (wajib). Jadi dengan kategori hukum ini, bila tidak memakai cadar tidak didapatkan suatu ancaman dari agama.

Sebagian partisipan menunjukkan bahwa hukum memakai cadar tidak secara mutlak dalam kategori hukum tertentu. Kategori hukum memakai cadar dapat menjadi sunah bahkan juga wajib. ${ }^{20}$ Tolak ukur dari perubahan hukum adalah situasi dan keadaan wanita pemakai cadar, artinya keadaan wanita yang cantik dan menarik yang dipandang dapat membawa mudarat baginya. Dalam keadaan seperti ini, hukum memakai cadar berbeda dengan hukum asalnya. Dengan alasan yang sama, partisipan pertama menunjuk hukum memakai cadar menjadi sunah. Sedangkan partisipan kedua menunjuk hukumnya menjadi wajib.

Dalam fikih, perubahan hukum sesuatu dari hukum asalnya memang telah jamak dikenal, seperti hukum dalam pernikahan yang hukum asalnya sunah dapat berubah menjadi wajib, makruh atau haram, sesuai dengan kondisi mempelai. Yüufu al-Qaradāāi menyebut ada lima faktor yang menyebabkan perubahan hukum, yaitu: sumbersumber dalil yang digunakan oleh para ulama, nas-nas Alquran yang bersifat umum, nas-nas yang menerima kemungkinan pemahaman, kondisi-kondisi yang bersifat khusus, dan perubahan fatwa karena waktu, tempat, dan situasi. ${ }^{21}$

Meskipun hukum memakai cadar bersifat anjuran (sunah) menurut ulama, para responden pemakai cadar memilih menggunakannya atas dasar manfaat yang dirasakan dalam aktivitas keseharian. Bahkan sebagian partisipan memilih kategori wajib untuk dirinya sendiri berdasarkan aspek kemanfaatan dan berusaha untuk konsisten memakainya. ${ }^{22}$ Berdasarkan hukum asalnya yang hanya bersifat anjuran, maka pada umumnya partisipan menyatakan dapat membuka cadar dalam kondisi tertentu atau ketika diminta untuk kepentingan tertentu. Sebagian mereka membuka karena kepentingan administrasi tertentu, dan sebagian lagi membuka karena pertimbangan hajatan keluarga yang dilaksanakan di rumah. Sebagian

${ }^{20} \mathrm{NY}$, Wawancara, Banda Aceh, 28 Juni 2018; AH, Wawancara, Banda Aceh, 27 Juni 2018.

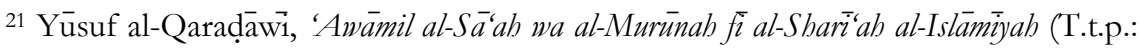
t.p., t.t), 15-74.

22TM, Wawancara, Banda Aceh, 28 Juni 2018. 
partisipan bahkan menyatakan membuka cadar ketika berada bersama tentangga di lingkungan rumah diperlukan. Di samping untuk dapat bersosialisi dengan baik, dapat dikenal, juga untuk kepentingan darurat, seperti kecelakaan dan sakit. Ketika itu terjadi dan orang tidak mengenalinya, ia memandang orang sulit memberikan pertolongan. ${ }^{23}$

Sedang dalam pandangan responden lain, pemakai cadar di kota Banda Aceh dan Aceh besar ini memandang pemakaian cadar bukan suatu keharusan. Memakai cadar dipandang lebih baik dalam kondisi yang dapat menimbulkan kenyamanan bagi perempuan. ${ }^{24}$ Mereka berpikir bahwa semakin cantik seorang wanita, semakin sulit laki-laki menundukkan pandangannnya. Para wanita ini umumnya menyatakan bahwa mereka mengetahui dan pernah mendengar atau membaca penjelasan tentang praktik isteri-isteri Nabi dan kaum Muslimah memakai cadar, seperti keberadaan ' $\bar{A}$ 'ishah yang memakai cadar, para isteri Nabi yang diminta berbicara di balik tabir, dan juga adanya perintah untuk mengulurkan pakaian ke seluruh tubuh. Pengetahuan ini mereka tingkatkan terutama ketika ingin membuat keputusan memakai cadar.

Sebagian besar responden tidak dapat menyebutkan dengan persis hadis tentang anjuran menggunakan cadar. Tetapi bagianbagian detail dari pemakaian cadar dapat disebutkan, seperti memakai cadar dianjurkan dalam warna seperti burung gagak, yakni berwarna hitam. Tetapi sebagian lain tidak mengetahui detail teknis menggunakan cadar. Pengetahuan tentang cadar sebagai sunah umumnya diperoleh dari sumber yang beragam. Kajian-kajian dalam kelompok kecil tertentu di kampus atau di luar kampus, video-video kajian tertentu, bacaan-bacaan tertentu yang merupakan merupakan media bagi wanita bercadar ini untuk mendapatkan pengetahuan mereka tentang cadar. Kajian-kajian dalam kelompok kecil di kampus atau di luar kampus tampak paling banyak mendominasi sebagai sumber pengetahuan tentang cadar dari sudut pandang agama.

Pengetahuan tentang cadar pada umumnya didapatkan oleh para responden setelah memiliki motivasi untuk bercadar. Dalam rentang waktu keinginan memakai cadar dengan tampil memakai cadar yang relatif lama, para responden mengembangkan pengetahuan mereka tentang cadar. Media yang paling banyak digunakan adalah media maya seperti website maupun video. Hal ini dikarenakan media ini

${ }^{23} \mathrm{IW}$, Wawancara, Banda Aceh, 29 Juni 2018.

${ }^{24}$ SS, Wawancara, Banda Aceh, 3 Juli 2018. 
dianggap paling praktis di banding menghadiri kajian-kajian. Namanama pemberi kajian yang paling banyak disebut adalah Ustad Abdul Somad (UAS) dan Ustadz Adli. Menurut mereka, kajian yang diberikan oleh dua ustadz ini memang berbasiskan hadis-hadis Nabi, praktis dan mudah dipahami.

Bila dianalisis dengan pendekatan tipologi kecenderungan pemikiran keagamaan, maka kajian-kajian dan video kajian yang diikuti dan buku-buku yang dibaca dapat dikatakan bertipologi 'salaf $\bar{i}$. Al Yasa Abubakar membagi pemikiran dan gerakan Islam dalam tiga

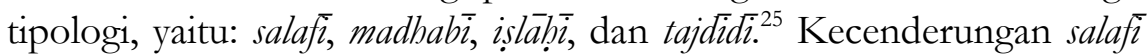
ini adalah ingin mengambalikan pemikiran dan praktek Islam awal seperti di kalangan sahabat dan tabiin. Praktek salafī tersebut dipahami dalam kecenderungan tekstual. ${ }^{26}$

Dari penjelasan tentang tentang pandangan wanita bercadar tentang sunah cadar, dapat dideskripsikan sebagai berikut:

Gambar 3

Persepsi Wanita Becadar tentang Cadar di Kotan Banda Aceh dan Aceh Besar sebagai sunah

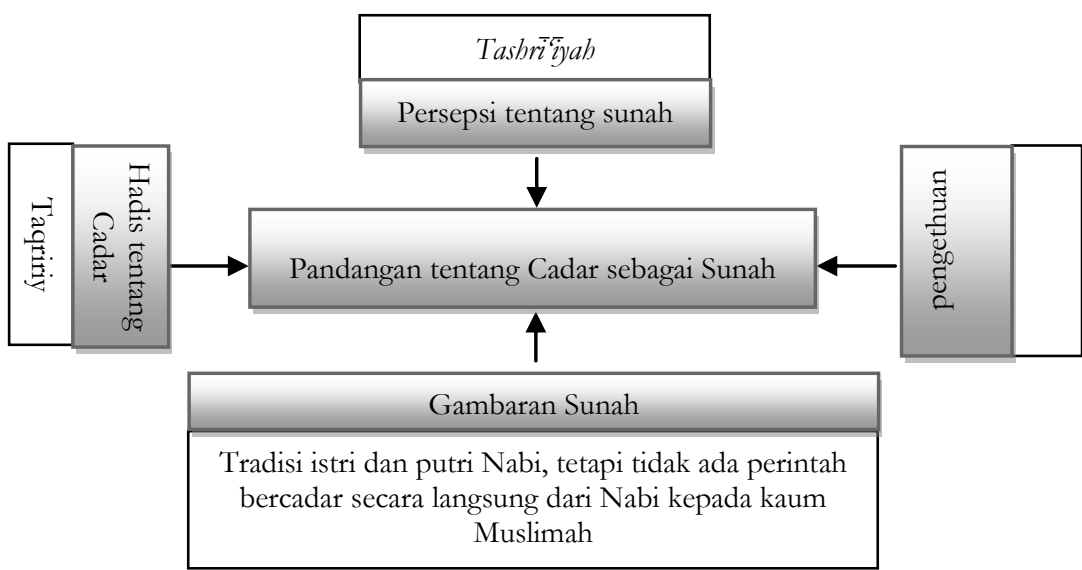

\section{Relgiusitas Wanita Bercadar}

Religiusitas dipahami sebagai komitmen religius (yang berhubungan dengan agama atau keyakinan iman) yang dapat dilihat melalui aktivitas

25 Al Yasa Abubakar, "Tajdid, Bagaimana Memahaminya”, dalam bttp://alyasaabubakar.com/2013/07/tajdid-bagaimana-memabaminya/, diakses tanggal 27 September 2018.

${ }^{26}$ Ibid. 
atau perilaku individu yang bersangkutan dengan agama atau keyakinan iman yang dianut. Religiusitas seringkali diidentikan dengan keberagamaan, sejauh mana pengetahuan, seberapa kokoh keyakinan, seberapa pelaksanaan ibadah dan kaidah dan seberapa dalam penghayatan atas agama yang dianutnya. Bagi seorang Muslim, religiusitas dapat diketahui dari seberapa jauh pegetahuan, keyakinan, pelaksanaan dan penghayatan atas agama Islam. ${ }^{27}$ Religiusitas memiliki beberapa dimensi seperti kepercayaan (idiological dimension), praktek agama (ritualistic dimension), pengetahuan (intelectual dimension), penghayatan (experiental dimension), pengamalan (conseguential dimension). ${ }^{28}$ Dengan demikian, religiusitas wanita bercadar dapat dilihat dari aspek-aspek tersebut.

Iffah, islāh dan izzah sangat dirasakan oleh wanita bercadar setelah mereka menggunakannya. 'Iffah secara bahasa bermakna pemeliharaan diri dari yang dilarang agama. Sedangkan secara definitif, memelihara kehormatan diri dari segala hal yang akan merendahkan diri, merusak dan menjauhkannya dari ajaran agama. ${ }^{29}$ Dalam Islam, 'iffah adalah sikap yang ditekankan pada setiap Muslim. Alquran maupun hadis Nabi sering mengungkapkan konsep ini. ${ }^{30}$ Fungsi 'iffah bagi seorang muslim adalah menjauhkan diri dari hal-hal yang dapat mengundang fitnah dan menghindarkan diri dari berbagai kehinaan dan kerendahan. ${ }^{31}$

'Iffah bisa dikategorikan ke dalam tiga hal, yaitu: 1) Memelihara diri dari pandangan kaum Adam; 2) Memelihara diri dari pergaulan yang lebih intens dan bersifat pribadi dengan lawan jenis; dan 3) memelihara diri dari teman-teman yang tidak sepikiran dan pada saat yang sama

\footnotetext{
${ }^{27}$ Fuad Anshori dan Rachmy Diana Mucharm, Mengembangkan Kreativitas Dalam Perspektif Psikologi Islam (Yogyakarta: Menara Kudus, 2002), 71.

${ }^{28}$ Jamaluddin Ancok dan Fuad Anshori Suroso, Psikologi Islam (Yogyakarta: Pustaka Pelajar, 1994), 77.

${ }^{29} \mathrm{Abu}$ Ahmadi dan Noor Salimi, Dasar-Dasar Pendidikan Agama Islam (Jakarta: Bumi Aksara, 2004), 208.

${ }^{30}$ Dalam Alquran surah al-Baqarah [2]: 173 disebutkan: “(Berinfaqlah) kepada orangorang fakir yang terikat (oleh jihad) di jalan Allab; mereka tidak dapat (berusaha) di bumi; orang yang tidak tabu menyangka mereka orang Kaya karena memelihara diri dari minta-minta. kamu kenal mereka dengan melihat sifat-sifatnya, mereka tidak meminta kepada orang secara mendesak. dan apa saja barta yang baik yang kamu nafkabkan (di jalan Allab), Maka Sesunggubnya Allah Maha Mengatabui". Sedangkan dalam hadis misalnya Nabi mengajarkan doa agar kita meminta diberi sikap 'iffah oleh Allah: "Ya Allah, aku memohon kepada-Mu petunjuk, ketakwaan, iffah, dan kecukupan." (HR. Muslim no. 6842 dari Ibn Mas‘ūd)

${ }^{31}$ Ahmad Umar Hasyim, Menjadi Muslim Kaffah (Yogyakarta: Mitra Pustaka, 2004), 336.
} 
membawa diri pada lingkungan pada orang yang baik. Para wanita dengan wajah berbalut cadar menyadari bahwa semakin cantik wanita semakin sulit bagi laki-laki menundukkan pandangannya. Demikian pula bagi wanita yang berstatus mahasiswi, atau yang memiliki peran publik, interaksi dengan kaum Adam nyaris tak terhindarkan. Interaksi ini memiliki peluang berlanjut pada interaksi yang lebih khusus secara personal. Dalam interaksi khusus seperti ini, pada umumnya kaum Adam mengambil peran yang lebih dominan dan agresif. Sementara wanita sendiri tidak berkeinginan untuk berinteraksi yang intens secara personal, baik karena alasan karena masih fokus pada studi maupun alasan menimbulkan fitnah bagi wanita yang sudah berkeluarga.

Di sisi lain, pengalaman lingkungan yang berbeda setelah menggunakan cadar dengan sebelumnya, membawa wanita-wanita bercadar ini merasa lebih terpelihara diri. ${ }^{32}$ Hal ini wajar, karena dorongan dan ketertarikan yang kuat terhadap kajian-kajian Islam membawa wanita bercadar pada pengalaman interaksi dengan Muslimah lainnya yang mungkin memiliki pengetahuan yang agam yang lebih luas sehingga menarik keinginan para pemakai cadar baru untuk meniru mereka. Inilah apa yang disebut Albert Bandura seperti yang dikutip Rahyubi bahwa perilaku individu tidak semata-mata refleks otomatis terhadap stimulus, melainkan juga akibat reaksi yang timbul antara lingkungan dan skema kognitif individu itu sendiri, ${ }^{33}$ yang lebih dikenal dengan teori imitasi dan modeling. Imitasi ini terjadi atas tiga faktor, yaitu: 1) minat dan perhatian yang cukup besar terhadap sesuatu, 2) sikap menjunjung tinggi atau mengagumi hal-hal yang diimitasi, dan 3) hal yang diimitasi memiliki penghargaan sosial yang tinggi.

Islăh dipahami sebagai meningkatnya pengetahuan tentang agama dan perilaku yang lebih baik. Hal ini didasari oleh pandangan bahwa wanita yang sudah memakai cadar ada dorongan untuk memiliki perilaku yang lebih baik. Dorongan ini disadari sebagai sebuah anugerah yang terkait dengan cadar yang mereka pakai. ${ }^{34}$ Perubahan perilaku ini sebagiannya didasarkan atas rasa malu. Artinya, cadar dapat meningkatkan rasa malu pemakainya, sehingga ia akan lebih berhati-hati dalam bersikap dan berperilaku. ${ }^{35}$ Para responden menyadari akan makna

\footnotetext{
${ }^{32} \mathrm{KP}$, Wawancara, Banda Aceh, 28 Juni 2018.

${ }^{33}$ Rahyubi, Teori-Teori Belajar dan Aplikasi Pembelajaran Motorik (Bandung: Referens, 2014), 10.

${ }^{34} \mathrm{RAR}$, Wawancara, Banda Aceh, 30 Juni 2018.

${ }^{35} \mathrm{AH}$, Wawancara, Banda Aceh, 27 Juni 2018.
} 
cadar sebagai sebuah pakaian kesempurnaan yang menuntut pemakainya menjadi seorang yang Islami. Baginya, hal-hal yang bagi sebagian orang tidak menjadi perhatian atau dipandang kecil, tetapi dalam pandangan partisipan ini tetap dapat merusak citra cadar sebagai pakaian Muslimah ideal. Dari sini dapat ditangkap bahwa dalam persoalan ringan dan kecil saja dia dapat menjaga sikap dan perilakunya, terlebih dalam hal-hal yang besar dan prinsipil. ${ }^{36}$ Meskipun mereka menyadari belum semua sisi aktivitas atau perilaku keagamaan mereka berubah menjadi baik, tapi perasaan adanya perubahan perilaku yang lebih baik pada diri dari sebelum dan sesudah menggunakan cadar sangat dirasakan.

Sedangkan perasaan 'izzah adalah perasan menjadi mulia di hadapan Allah dan Rasul. Perasaan 'irzab ini merupakan kelanjutan dari pearasaan iffah dan islăh. Keasadaran diri pada kemampuan memelihara diri dan perbaikan perilaku menimbulkan rasa mulia sebagai wanita Muslimah karena mampu mengikuti sunah, meneladani isteri-isteri Rasulullah dan sahabat Nabi dari kaum Muslimah. Di sisi lain, perasaan 'izah ini juga muncul karena sebagian mereka juga menjadi tempat bertanya tentang Islam. Ini berarti bahwa cadar yang mereka gunakan dapat menjadi simbol identitas akan pemahaman Islam yang lebih dalam. Karena itu, wanita yang sudah bercadar lebih hati-hati dalam bertindak dan berperilaku. Di samping itu wanita bercadar juga termotivasi untuk meningkatkan frekuensi dalam mengikuti kajian-kajian rutin, berselancar di dunia maya tentang ajaran Islam, maupun membaca buku-buku tentang Islam.

Perasaan religius lain yang diungkapkan oleh para responden adalah mereka merasa dianugerahi Allah teman-teman yang lebih baik dalam pandangan mereka, yaitu teman-teman yang telah 'hijrah' ke dalam pakaian Muslimah dan lebih memberikan perhatian tentang pengetahuan keislaman dan perilaku Muslimah. Sikap dan perhatian teman-teman berkenaan dengan keberislaman memotivasi wanita-wanita ini untuk mewujudkan sikap dan perhatian yang sama.

Relegiusitas ini terutama banyak diungkapkan oleh wanitawanita yang bermotivasi perlindungan diri dan bermotivasi teologis dalam bercadar. Hal ini barangkali disebabkan oleh faktor ekternal yang memberi makna pada pakaian cadar yang mereka pakai.

${ }^{36}$ SS, Wawancara, Banda Aceh, 3 Juli 2018. 


\section{Gambar 4}

\begin{tabular}{|c|c|c|}
\hline \multicolumn{2}{|c|}{$\begin{array}{c}\text { Religiusitas Wanita Becadar di Kotan Banda Aceh dan Aceh } \\
\text { Besar sebagai Sunah }\end{array}$} & ceh \\
\hline Iffah & Islāh & Trzah \\
\hline $\begin{array}{l}\text { - Memelihara diri dari pandangan } \\
\text { kaum Adam } \\
\text { - Memelihara diri dari pergaulan yang } \\
\text { lebih intens dan bersifat pribadi } \\
\text { dengan lawan jenis } \\
\text { - Memelihara diri dari teman-teman } \\
\text { yang tidak sepikiran dan pada saat } \\
\text { yang sama membawa diri pada } \\
\text { lingkungan pada orang yang baik. } \\
\text { - Menjaga batas waktu pulang ke } \\
\text { rumah pada malam hari }\end{array}$ & $\begin{array}{l}\text { - Tahsinin al-Qur'an } \\
\text { - Menambah } \\
\text { pengetahuan tentang } \\
\text { Islam dengan } \\
\text { mengikuti dawrah, } \\
\text { membaca buku, } \\
\text { browsing tentang Islam } \\
\text { - Lebih mudah } \\
\text { menerima ketentuan } \\
\text { Allah } \\
\text { - Menghilangkan } \\
\text { kebiasan buruk }\end{array}$ & $\begin{array}{l}\text { - Berada dalam diri } \\
\text { terpelihara dari } \\
\text { pandangan } \\
\text { ikhwan } \\
\text { - Tempat orang } \\
\text { bertanya tentang } \\
\text { Islam } \\
\text { - Memiliki teman- } \\
\text { teman yang } \\
\text { memberi } \\
\text { motivasi berislam }\end{array}$ \\
\hline
\end{tabular}

Dari dekripsi di atas, dapat dilihat bahwa religiusitas wanita bercadar ini terlihat dalam fungsi sosio-moral dan psikologis. Dari fungsi sosio-moral, cadar yang mereka gunakan telah mengurangi tingkat pelanggaran terhadap etika-etika kewanitaan yang dipersepsi oleh masyarakat. 'Iffah yang tertuang dalam sikap memelihara diri mereka dari pergaulan yang "tanpa batas" dengan lawan jenis di warung-warung kopi atau di tempat-tempat lain, menjaga batas waktu pulang ke rumah pada malam hari akan mengurangi fitnah-fitnah di tengah masyarakat, sehingga kehidupan masyarakat menjadi lebih tertib. Dalam konteks Aceh yang secara administratif menerapkan syariat Islam, fungsi ini tentu menjadi sangat penting. Di samping sebagai penerapan syariat Islam, cadar juga bisa membawa identitas bahwa masyarakat Aceh betul-betul bersyariat, tidak hanya secara formal, tetapi juga secara informal.

Sedangkan dari fungsi psikologis, religiusitas wanita bercadar membawa wanita bercadar ini memiliki hidup yang lebih berarti. Islăh dan iqzah yang tertuang dalam upaya terus memperbaiki diri dengan memperbaiki baca Alquran, menambah wawasan keislaman, menghilangkan sifat buruk dan menumbuhkan sifat-sifat baik, dan menjadi tempat bertanya bagi wanita-wanita lainnya, membawa religiusitas ini pada hidup berarti dan bermakna. 


\section{Penutup}

Dari hasil dan pembahasan di atas, maka dapat disimpulkan sebagai berikut bahwa: pertama: ada lima motivasi wanita bercadar di Kota Banda Aceh dan Aceh Besar, yaitu: a) motivasi perlindungan diri, b) motivasi teologis, c) motivasi rasa nyaman, d) motivasi menyenangkan keluarga, dan e) motivasi mengikuti aturan. Tetapi motivasi yang dominan di kalangan wanita pemakai cadar di Kota Banda Aceh dan Kabupaten Aceh adalah motivasi perlindungan diri, baik dari catcalling maupun dari situasi yang tidak baik dalam pandangan agama dan sosial. Dengan demikian, cadar memiliki makna sebagai medium perlindungan dan perbaiki diri. Mewujudkan diri untuk tampil secara bercadar memiliki tantangan tersendiri. Tantangan dari dalam diri adalah perasaan kelayakan untuk memakai cadar, karena dia dipandang sebagai pakaian takwa. Tantangan dari luar datang dari keluarga, terutama orang tua yang tidak setuju dengan pakaian cadar. Tetapi hal ini disiasati dengan langkah menggunakan masker secara konsisten setiap akan beraktivitas di luar.

Wanita yang memakai cadar meyakini bahwa cadar adalah sunah, seperti dipraktikan oleh isteri-isteri Nabi dan kaum Muslimah awal. Keyakinan ini pada umumnya diperoleh dari pengajian-pengajian rutin tentang Islam yang mereka ikuti. Banyak dari wanita yang memakai cadar ini tidak dapat menyebutkan hadisnya secara detail, namun menyatakan pernah mendengarnya. Adapun pemahaman mereka tentang sunah cadar berpola ideal totalistik. Semua sunah bersifat tashri $\%$, yaitu sunah dimaksudkan sebagai syariat dan untuk diikuti. Atas dasar itu, maka tidak perlu dipertimbangkan illab (sebab) penetapan suatu sunah. Karena itu aspek tanakkur (penyamaran) dalam penggunaan cadar yang disebut dalam hadis al-Bukhärì dan Ibn Majah tidak menjadi perhatian sama sekali. Dari segi hukum, memakai cadar dinyatakan sebagai sunnah oleh umumnya wanita bercadar. Karena itu, dalam situasi tertentu, mereka boleh melepaskan cadar yang mereka pakai. Sebagian memilih kategori wajib untuk dirinya sendiri atas dasar manfaat cadar yang telah dirasakan.

Wanita yang memakai cadar ini umumnya mengalami peningkatan religiusitas setelah menggunakan cadar. Religiusitas ini tersimpul dalam perasaan 'iffah, ișlăh dan 'izzah yang dirasakan oleh wanita bercadar setelah mereka menggunakannya. Iffah adalah pemeliharaan diri sebagai perintah agama bagi wanita. Ișlăh merupakan upaya perbaikan diri ke arah yang lebih baik. Sedangkan perasaan 
'izzah adalah perasaan mulia dan berharga dihadapan Allah dan Rasul. Perasaan 'izzah ini merupakan kelanjutan dari pearasaan 'iffah dan ișlăh. Adapun manfaat religiusitas wanita bercadar terlihat dalam dua aspek, yaitu aspek sosio-sosio moral dan aspek psikologis.

\section{DAFTAR PUSTAKA}

Abdullah, Syamsuddin. Agama dan Masyarakat: Tinjanan Sosiologi Agama. Jakarta: Logos Wacana Ilmu, 1997.

Abubakar, Al Yasa. "Tajdid, Bagaimana Memahaminya", dalam http:// alyasaabubakar.com/2013/07/tajdid-bagaimana-memabaminya/.

Ash'ath (al), Abū Dāwūd Sulaymān. Sunan Abī Dāwñd. Riyad: Bayt alAfkār al-Dawliyah, t.th.

Aziz, Sholehuddin Abdul. 'Misteri Di Balik Wanita Bercadar ???', dalam wnw.kompasinia.com. Diakses pada 21 April 2019.

Bukhārì (al), Abū 'Abd Allāh Muhammad b. Ismā̄ill. Sahị̄h al-Bukhārì. Beirut: Dār Ibn Kathìr li al-Ṭibā'ah wa al-Tawzī', 2002.

Geertz, Clifford. Kebudayaan dan Agama. Yogyakarta: Kanisius, 1992.

Ghazali (al), Muhammad. Dari Hukum Memakai Cadar Hingga Hak Isteri yang Ditalak Tiga. Jakarta: Mizania, 2015.

Gufron, Nur, \& Rini Risnawati. Teori-teori Psikologi. Yogyakarta: Ar-Ruzz, 2011.

Hasyim, Ahmad Umar. Menjadi Muslim Kaffah. Yogyakarta: Mitra Pustaka, 2004.

Hidayatulloh, Haris. "Pemikiran Muhammad Nāșiruddin al-Albāniy Tentang Jilbab dan Cadar Wanita Muslimah," dalam Religi: Jurnal Studi Islam, Vol. 12, No 2 (2012).

Irawan, I.B. Teori-Teori Sosial dalam Tiga Paradigma: Fakta Sosial, Definisi Sosial, Perilaku Sosial. Jakarta: Kencana, 2015.

Ismāīil, Muhammad Aḥmad. Al-Radd al-Tlmì ala Kitāb Tadhkirat al-Aș̣āb bi Taḅrim al-Niqäb. t.tp: Dār al-Imān, t.th.

Jakfar, Tarmizi M. Otoritas Sunab Non-Tasynizyyah Menurut Yusuf AlQaradhawi. Yoyakarta: Ar-Ruz Media, 2011.

Jumadi. "Analisis terhadap Hadis yang Dijadikan Dasar Memakai Cadar Bagi Perempuan," dalam bttp://ushuluddin- 
minsuska.blogspot.co.id/2012/12/analisis-terhadap-badis-yangdijadiakan.html, diakses tanggal 19 September 2017). Diakses tanggal 20 September 2017.

Mājah (Ibn), Muḥammad b. Yazid al-Qazwinini. Sunan Ibn Mājah. Riyad: Dār al-Ma árif li al-Nashr wa al-Tawżi‘, t.th.

Mucharm, Fuad Anshori dan Rachmy Diana. Mengembangkan Kreativitas Dalam Perspektif Psikologi Islam. Yogyakarta: Menara Kudus, 2002.

Marzūq, 'Abd al-'Aziziz. Al-Hijäb fi al-Shar' wa al-Fịtrah. Riyad: Maktabah Dār al-Manāhij, $1436 \mathrm{H}$.

Muhajir, Noeng. Metodologi Penelitian Kualitatif. Yogyakarta: Rake Sarasin, 1993.

Naysābūrì (al), Abū al-Husayn Muslim b. Al-Hajjàj. Saḅịh Muslim. Beirut: Dār al-Kutub al-'Tlmiyah, 1991.

Novri, Mutiara Sukma dan Nova Yohana. "Konstruksi Makna Cadar Oleh Wanita Bercadar Jamaah Pengajian Masjid Umar bin Khattab Kelurahan Delima Kecamatan Tampan Pekan Baru," dalam Jurnal Online Mabasiswa (JOM) Bidang Ilmu Sosial dan Ilmu Politik, Vol 3, No 1 (2016).

Nursalam. "Persepsi Masyarakat tentang Perempuan Bercadar," dalam Jurnal Equalibrium, Vol. 2, No. 2, (2017).

Odea, Thomas F. Sosiologi Agama: Suatu Pengantar. Jakarta: Rajawali Press, 1993.

Qardhawi (al), Yusuf, Al-Sunnah Masdar li Al-Ma'rifah wa al-Hadärah. Mesir: Dār al-Shurūq, 2002.

-, Keluasan Dan Keluesan Hukum Islam, terj. Agil Husein AlMunawwar. Semarang: Bina Utama, 1993.

Rahyubi. Teori-Teori Belajar Dan Aplikasi Pembelajaran Motorik. Bandung: Referens, 2014.

Rahayu, Wiga. "Profil Wanita Bercadar (Studi Kasus Wanita Salafi di Kelurahan Tangkerang Timur Kecamatan Tenayan Raya Kota Pekanbaru)", dalam Jumal Online Mahasiswa (JOM) Bidang Ilmu Sosial dan Ilmu Politik, Vol 3, No 1 (2016).

Rahman, dkk. "Motivasi, Stigma, dan Coping Stigma pada Perempuan Bercadar," dalam Jurnal Psikologi Teori dan Terapan, Vol. 7, No. 2, (2017). 
Ratri, Lintang. "Cadar, Media, dan Identitas Perempuan Muslim," dalam FORUM, Vol 39, No 2 (2011).

Salimi, Abu Ahmadi dan Noor. Dasar-Dasar Pendidikan Agama Islam. Jakarta: Bumi Aksara, 2004.

Suroso, Jamaluddin Ancok dan Fuad Anshori. Psikologi Islam. Yogyakarta: Pustaka Pelajar, 1994.

Suryadilaga, Alfatih. 'Model-Model Living Hadis,' dalam Metodologi Penelitian Living Qur'an dan Hadis. ed. by Sahiron Syamsuddin. Yogyakarta: TH Press, 2007.

Suryadilaga, M. Alfatih, Implementarsi Pendekatan IntegrasiInterkoneksi Dalam Kajian Living Hadis, Dalam Islamic Studies; Paradigm Integrasi-Interkoneksi: Sebuah Antologi. Yogyakarta: Suka Press, 2007.

Syal (al), Jabir. Profil di Balik Cadar: Kisah Wanita dalam Alquran. Jakarta: Pustaka Utama Grafiti, 1987.

Tausikal, Muhammad Abduh. "Mamakai Cadar di Saudi Arabia," dalam http:// rumasho.com/2518-memakai-cadar-di-saudi-arabia.html. Diakses tanggal 18 September 2017. 